\title{
Breaking the cycle: Creating a sustainable agricultural system
}

\author{
Review by Stacey F. Stearns, University of Connecticut \\ Cooperative Extension System *
}

Review of In Defense of Farmers: The Future of Agriculture in the Shadow of Corporate Power, edited by Jane W. Gibson and Sara E. Alexander. (2019). University of Nebraska Press. Available as hardcover and ebook; 422 pages. Publisher's website: https://www.nebraskapress.unl.edu/university-of-nebraskapress/9781496206732

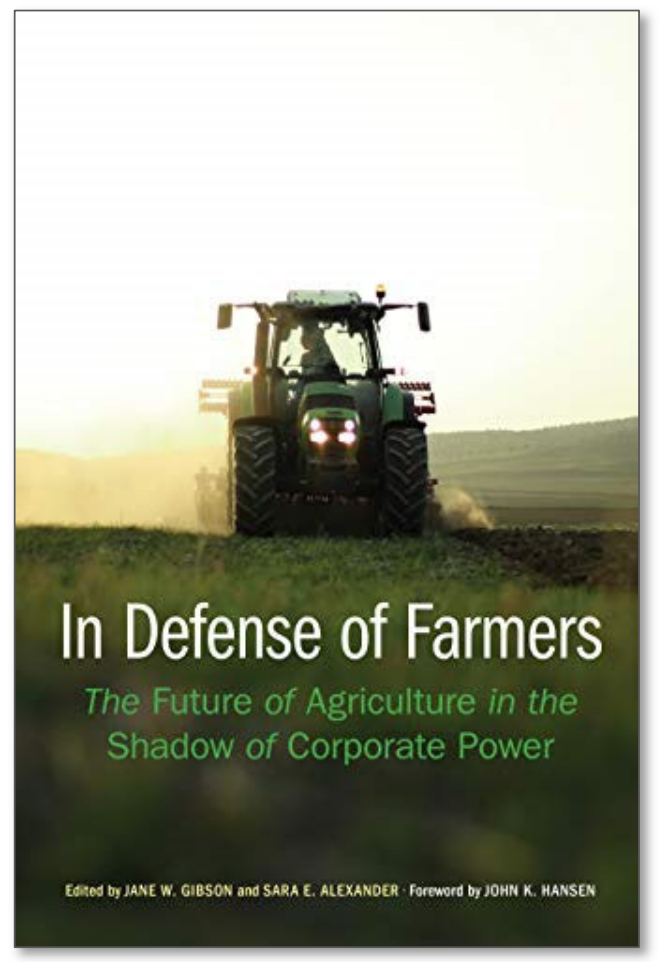

Submitted April 7, 2020 / Published online May 18, 2020

Citation: Stearns, S. F. (2020). Breaking the cycle: Creating a sustainable agricultural system [Book review]. Journal of Agriculture, Food Systems, and Community Development, 9(3), 333-335. https://doi.org/10.5304/jafscd.2020.093.029

Copyright (C) 2020 by the Author. Published by the Lyson Center for Civic Agriculture and Food Systems. Open access under CC-BY license.

\begin{abstract}
A griculture is currently in an unsustainable Acycle created by the industrial food system. Breaking that cycle and creating a sustainable agriculture system will not be easy and requires dramatically altering the food system framework.

\footnotetext{
* Stacey F. Stearns is a program specialist at the University of Connecticut Cooperative Extension System; her focus is communications and agricultural programs. She also is part of the tenth generation on her family's vertically integrated 500cow dairy farm. The farm produces and processes milk for local communities through home delivery and wholesale partners. She can be contacted at University of Connecticut Cooperative Extension System, 1376 Storrs Road, Unit 4134, Storrs, CT, 06269-4134 USA; +1-860-486-9228;
} stacey.stearns@uconn.edu.
\end{abstract}

In Defense of Farmers: The Future of Agriculture in the Shadow of Corporate Power, edited by Jane W. Gibson and Sara E. Alexander, examines parts of the history of industrial agriculture, the current situation, and a potential future. The book would be valuable for food system leaders and policy-makers and in graduate seminars. Analyses of examples of industrial agriculture in the United States, Canada, Brazil, and Bolivia highlight unsustainable methods and suggest improvements that could serve as a starting point for dialogues and decisions on changing the food system framework.

A myriad of political, corporate, and other factors has shaped our current agricultural and food system instead of the farmers. The authors describe 
how farmers have become pawns on the industrial agriculture chessboard. Large multinational corporations control the chessboard and, through political power moves, have disproportionate control of the food system. Industrial agricultural systems have promoted myths as facts and use their force to control the agricultural framework. The authors work to dispel the myths and provide facts through case studies for why this is an unsustainable cycle.

There are two polarized viewpoints of farmers; they are either heroes or villains. Most farmers operate a family farm, and forces beyond their control, including politics, economics, and ecology, challenge all of them. Our collective future depends on our ability to change the framework of the agricultural system. Separating farmers into industrial and alternative agriculture divides the group and hinders the collective voice and decision-making of farmers for changing the framework. Farmers, consumers, communities, and the environment need the benefits of farming for our continued survival and growth.

The book's 10 chapters cover three themes: the history of agriculture, our present position, and a potential improvement and path forward. The first few chapters look at the history of horizontal and vertical integration within agriculture. These include agribusinesses such as seed, chemical, genetic, and machinery companies. Their horizontal integration leaves farmers with few choices and little competition allows the companies to set their own price points.

The United States and Bolivia have seen industrialization of the poultry industry through vertical integration, where a company controls all parts of the process, from the inputs through the final product. Other sectors of agriculture, including beef and pork, are mirroring the vertical integration of the poultry industry and that could have disastrous results for our food system because farmers have no authority or control. Farmers who do not contract with a vertically integrated company cannot compete with the economies of scale and provide a viable product. These vertically integrated national and multinational companies control the farm, food, and antitrust policies that manage the agricultural framework.

In the discussion on our present state, Gibson refers to technology as the fourth industrial revolution, noting that it is permeating every aspect of farms. Adopting automation distances the farmer from the land and ecosystem. She further explains how automation hinders sustainable agriculture systems. Next, we see a case study of groundwater depletion by California vineyards during the recent drought. Politics, power, and struggles to determine who is responsible for costs surround the complex system and regulatory attempts to manage groundwater as a resource. Regulatory systems cannot address industrial agricultural issues unless the framework is changed.

Case studies of Texas wheat farmers show that risk is about more than economics and productivity. Climate change will magnify the risks taken by all farms. Knowledge control by agribusinesses further diminishes the ability of farmers to make their own decisions. Instead, farmers rely on increasing their productivity to address diminishing profits. However, consolidation of farms into operations with larger acreage has destabilized rural communities. The structure of agricultural systems controls decisions made by farmers, but we can change that structure if we start looking at food security as national security. Family farms are the systems that provide food security, and if we shift the viewpoint, the agricultural structure will change.

The final chapter summarizes errors of previous production methods and offers ideas for how agriculture could be reshaped. John Ikerd suggests that we work together through small actions that begin on the community level, similar to the community actions taken in response to global climate change. Building sustainable agriculture systems in communities could lead to broader impacts and positive effects on the entire food system. Addressing food justice issues, supporting locally grown agricultural products, and helping farmers access land are all actions that can help confront the issues created by industrial agriculture. Economics measured in sales and profitability cannot be the only metric used to define success. Readers can use what they learn from this book to start dialogues and begin changes to curtail industrial agriculture and help support all farmers.

Changing the framework of agriculture and food systems is a critical need highlighted by the 
industrial agriculture issues outlined in the book. The authors offer a limited number of suggestions or actions. Ikerd proposes a way forward in the last chapter through the community food utilities that could function like other public utilities. However, changing our food system will require addressing food system monopolies on the national and global levels as well.

There is more than one solution, and this book uses an anthropologic approach to explore what is not working and offer a potential resolution. We as agriculturalists need to work on rebuilding the system and creating new frameworks that support and protect smaller-scale operations.

If we are to stand in defense of the farmer, as the book title suggests, we must change our agricultural framework and disband large monopolies while supporting and strengthening local farmers. Regulatory changes, antitrust laws, and cooperative models will be required for large changes in the framework. This will only happen through a concentrated effort that involves farmers, policy-makers, communities, and consumers across agricultural sectors, nationally and globally. 